\title{
On foliar fungal pathogens at species of the genus Alnus Mill. in Siberia
}

\author{
Mariya A. Tomoshevich*, Irina G. Vorob'eva, and Evgeny V. Banaev \\ Central Siberian Botanical Garden of the SB RAS, 630090 Novosibirsk, Russia
}

\begin{abstract}
The article determines the species composition of causative agents of plant leaf diseases of the genus Alnus Mill. for the Siberian region, that grow in the arboretum collections and urbanized environment. The author has identified four phytopathogens, their spread and harmfulness are specified; established the confinement of foliar fungal pathogens to the host plant species, its ontogeny phase, and abiotic environmental factors. It had been found a hyperparasite Ramularia uredinis (W. Voss) Sacc. on a causative agent of alder rust (Melampsoridium alni (Thum.) Dietel), for which this phytopathogen is a new host.
\end{abstract}

\section{Introduction}

The genus Alnus Mill. includes about 30 species, most of them are spread in the Northern Hemisphere. Species of the genus Alnus are polymorphic and have a large number of decorative varieties, which makes them promising as landscaping objects in Siberian cities and towns. In this regard, it is necessary to study the pathogenic mycobiota capable to affect the resistance and decorativeness of alder species in culture. This is especially true for leaf pathogens. In addition, due to the wide prevalence of a number of alder species and their different coenotic confinement, the study of concomitant mycobiota within the range taking into account various environmental factors is interesting, undoubtedly.

The literature analysis showed poorly studying of these issues in the world. The alder phytopathogens are most studied in the United States, where e.g. 47 fungi parasitizing on leaves have been identified for A. rubra Bogard. [1]. As for other Alnus species, their number varies from 0 to 13 (Fig. 1).

When assessing the prospects of these plant practical use in landscaping, one should take into account data on the parasitic mycobiota. To study the biodiversity and geographical distribution of phytopathogens, variations in the development cycles and use of new nutrient substrates are revealed. Siberia.

The paper objective is to present studying results of the alder pathogenic mycobiota in

* Corresponding author: arysa9@mail.ru 


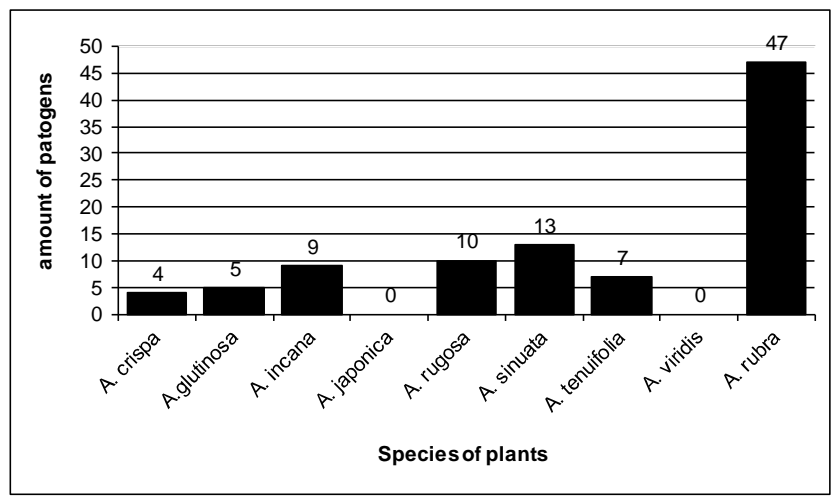

Fig. 1. The number of phytopathogens in the species of the genus Alnus in the USA [1]

\section{Materials and Methods}

Investigations of 4 species leaves pathogens of the genus Alnus - A. fruticosa Rupr., A. glutinosa (L.) Gaertn., A. hirsuta (Spach.) Turcz., Alnus incana (L.) Moench. [2] were carried out on plants growing in reserves, arboretums and plantations of five Siberian cities: Novosibirsk, Krasnoyarsk, Barnaul, Tomsk and Kemerovo.

The phytopathological study of the model territories was surveyed using a detailed route method during the growing seasons of 2005-2019, annually from May to September, every 10 days in the arboretum of the Central Siberian Botanical Garden of the Siberian Branch of the Russian Academy of Sciences and Novosibirsk city, annually at least twice a season during systematic trips - at other model territories.

When detecting diseases, affected parts were recorded, descried, selected and laid in the herbarium to identify the pathogen. The fungi identification was carried out at the Central Siberian Botanical Garden of the Siberian Branch of the Russian Academy of Sciences and the Biological Institute of the Russian Academy of Sciences. A microscope by CARL ZEISS Axiolab and Discovery V4 and a Hitachi TM-1000 scanning electron microscope were used. The fungi structures were measured with an eyepiece micrometer on an MBI-3 microscope. A new species of sporodochial micromycete was identified and described by Prof. Uwe Braun, Halle/S., Germany.

\section{Results}

The phytopathological monitoring of plant species of the genus Alnus revealed four causative agents of leaf diseases that occur annually or periodically: Cheiromycella foliicola U. Braun, Melnik \& Tomoshevich, Melampsoridium alni (Thum.) Dietel, Erysiphe penicillata (Wallr.) Link, Mycopappus alni (Dearn. et Barthol.) Redhead et GP White. The fungus Ramularia uredinis (W. Voss) Sacc. was marked as a hyperparasite of the rust fungus Melampsoridium alni.

The fungus Melampsoridium alni causes alder rust. The disease first signs are manifested in mid-July. Uredinia is formed on the leaf underside, yellowish spots appear on the upper side at the same place. Uredinia are scattered or grouped on yellowish or reddish sites, round, 0.1-0.4 mm diameter, yellow. Urediniospores are oblong-clavate or linearly elongated, 25-45 x 8-17.5 $\mu \mathrm{m}$, orange-yellow; the sheath is fine acanthaceous with a smooth apex; paraphyses are rudimentary. By late August, brown-black telia are formed on the leaf underside, scattered or in groups, rounded, 0.3-0.5 mm diameter, reddish-brown or 
blackish-brown. Teliospores are oblong-clavate or prismatic, 45-50 x 10-12 $\mu \mathrm{m}$, the sheath is yellow-brown, smooth. In Siberia, the fungus infects Alnus fruticosa and is found wherever this species grows.

The hyperparasite Ramularia uredinis was found in uredinia at many herbarium specimens of leaves infected with rust (Fig. 2).

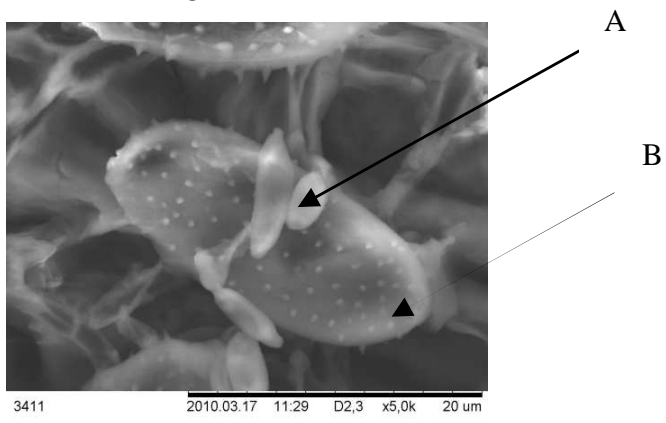

Fig. 2. Hyperparasite Ramularia uredinis (W. Voss) Sacc.: A - ramularia spores; B - spore of rust

The pathogen Erysiphe penicillata causes powdery mildew on leaves of the genus Alnus species (Fig. 3). The disease first signs are found at the end of July. A thin, cobweb film forms on both lamina surfaces, more often on the upperside, sometimes it occurs as plaques on the leaf underside. Fruiting bodies are formed in August on both leaf sides. The phytopathogen infects Alnus fruticose, but does not cause significant harm in Siberia.

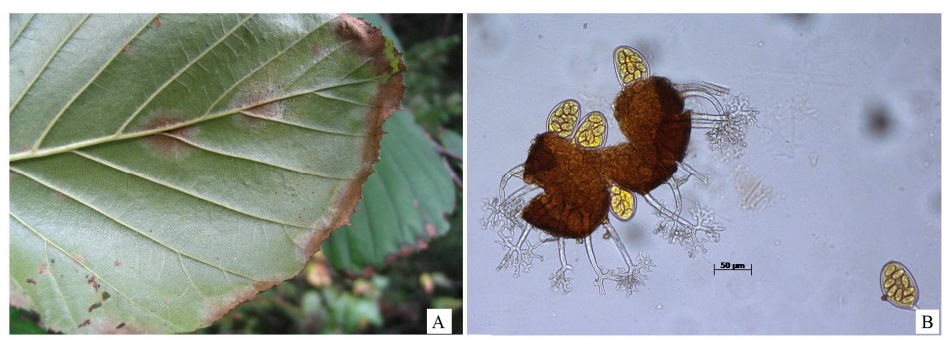

Fig. 3. Powdery mildew on Alnus fruticosa: A - bloom on the underside of the leaf; B - chasmothecia of the fungus in a scanning microscope; $\mathrm{C}$ - chasmothecia of the fungus with asci and ascospores.

The fungus Cheiromycella foliicola was found in Siberia in the Nature Reserve "Stolby" (Krasnoyarsk) and the Central Siberian Botanical Garden of SB RAS arboretum (Novosibirsk). Sporodochia are punctate, dark brown to black, 40-100 $\mu \mathrm{m}$ diameter, dusty. Conidiophores are simple or branched, developing from stromal cells, composed mainly by swollen conidiogenic cells (Fig. 4). Conidia are smooth, olive or olive-brown, sometimes simple broadly ellipsoidal or oblong obovate, usually with 2-5 transverse, sometimes 1 (2) oblique longitudinal septum, 20-35 x 6-12 $\mu \mathrm{m}$, but more often branched, consisting of obovoid and rhomboid unicellular base, 10-15 x 6-12 $\mu \mathrm{m}$ and two scions consisting of 2-5 cells, 15-35 x 7-12 (-14) $\mu \mathrm{m}$. The scions are almost equal in length. The conidia total length is $25-45 \mu \mathrm{m}$, as a rule, with 4-6 septa (constrictions), branches of conidia are 7-12 (14) $\mu \mathrm{m}$ wide.

The pathogen colonizes necrotic spots caused by the rust fungus Melampsoridium alni on the leaves of Alnus fruticosa. 


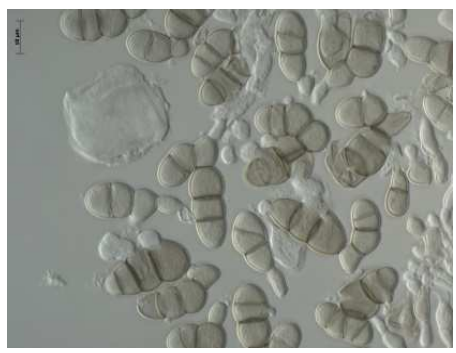

Fig. 4. Cheiromycella foliicola U. Braun, Melnik \& Tomoshevich

The fungus Mycopappus alni (Fig. 5), belonging to Mycelia sterilia group, was found in the arboretum of the Central Siberian Botanical Garden of SB RAS on Alnus incana and A. glutinosa. The disease first symptoms appear in mid-late July as small scattered light brown specks of 1-2 mm diameter, located over the entire lamina surface, mainly on the lower branches. Later, the spots merge, can reach up to $20 \mathrm{~mm}$ diameter, round or angular, pale olive or olive-brown, gray in the center, indistinctly limited or with an uneven darker border. The spots often have concentric zoning. On the upper side of the leaves or leaf adjacent green parts, whitish tufts (fungal propagules) appear on the spots, which can be easily removed from the leaf, they collect in groups or are scattered (Fig. 5A). The propagules making up these tufts are colorless, 170-275 x 344-576 $\mu \mathrm{m}$, they consist of a relatively free stromatic base (glomerulus) 56-90.4 x 37-56 $\mu \mathrm{m}$, which extends with branched monilioid-type cells, giving rise to numerous long filaments (Fig. 5 B). Filaments of 175-339 $\mu \mathrm{m}$ long and 3.6-5.4 $\mu \mathrm{m}$ wide are wider, septate, smooth near the base, and blunt at the apex.

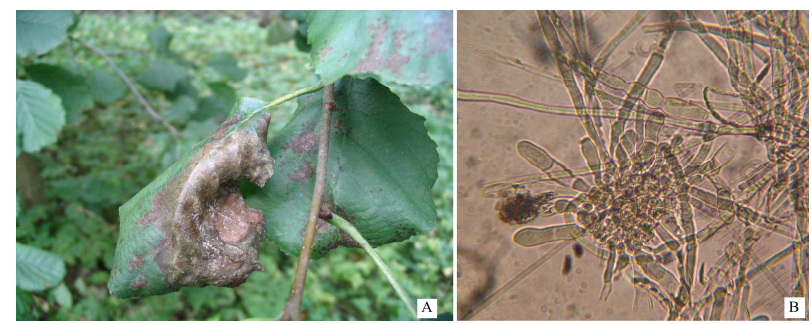

Fig. 5. Fungus Mycopappus alni (Dearn. et Barthol.) Redhead et G.P. White.: A - leaf spots; B fungus propagules.

The disease spreads to the middle branch tier in two-three weeks. The spots increase up to 5-15 mm, acquire an olive-brown color, merge. White or white-pinkish bloom forms on them at high humidity. Sporulation of the fungus is arranged in the form of rings, ribbons, or separate groups. Leaf twisting and dropping are observed on the lower branches. Damage to leaves on a branch is $80-100 \%$. The fungus development and harmfulness depend on weather conditions to a large extent (the presence of warm and humid weather in June-July). The spread and harmfulness of the disease were significant in the arboretum of Central Siberian Botanical Garden of SB RAS. Probably, the pathogen infects alders in urban plantings and natural habitats.

The seasonality of pathogens development has been revealed. Erysiphe penicillata and Mycopappus alni populate plant leaves the first (mid-June-July), pathogens Melampsoridium alni and Cheiromycella foliicola are confined to the second half of the growing season (August-September). Under favorable conditions, the phytopathogen development continues until September included. The host plants for Erysiphe penicillata, Melampsoridium alni, and Cheiromycella foliicola are A. fruticosa, and for Mycopappus alni-A. glutinosa and A. incana. No pathogens were found on A. hirsuta in Siberia. 


\section{Discussion}

Long-term monitoring of leaf diseases of the genus Alnus plants has demonstrated that a limited range of phytopathogens develops on them under Siberian compared with other regions. A. fruticosa, naturally growing in Krasnoyarsk, has the largest number of pathogens, and only one pathogen, Mycopappus alni, was found on the introduced $A$. glutinosa and A. incana. The first information on finding M. alni in Russia dated back 2005 [3], although the earliest records of this fungus were made in Canada and the United States in 1985, where it was found on Alnus rubra and A. sinuate [4]. Later, M. alni was recorded in Turkey on leaves of Pyrus sp. and Betula spp. [5], and in Korea - on pear and willow [6,7]. At present, at the Siberian territory, the fungus parasitizes only on A. glutinosa and A. incana, however, there is a possibility of finding it on other plant species. Our research has established a feature of the fungus - its sporadic appearance (there is a complete absence of the disease symptoms in some years).

The sporodochial micromycete Cheiromycella foliicola in Siberia was originally found in the Nature Reserve "Stolby" (Krasnoyarsk) on Alnus fruticosa in its natural habitat [8]. Further, this pathogen was registered by us in the arboretum of the Central Siberian Branch of SB RAS, $800 \mathrm{~km}$ west of the original find, and on Alnus fruticose as well [9]. This fact suggests a possible wider distribution of this fungus in nature. At the same time, in contrast to Mycopapus, this micromycete was not found on alder of other subgenera (in particular, on species of the subgenus Alnus), which may indicate its narrower specialization.

The literature contains information on the parasitism of the fungus Ramularia uredinis in the uredinia of rust fungi of the genera Cronartium, Melampsora, Melampsoridium, and Pucciniastrum [10,11]. However, the rust fungus Melampsoridium alni is a new host of this hyperparasite.

There are a limited number of phytopathogens affecting alder under Siberian conditions. Foliar fungal pathogens have been found only on three of four plant species of the genus Alnus growing at this area. The timing of the pathogen appearing is extended during the growing season, and is determined by environmental conditions. The identified pathogens do not belong to highly specialized species, therefore, it is possible to detect them on new host plants, as well as their distribution to new territories.

\section{References}

1. D. Farr, Fungi on plants and plant products in the United States (Minnesota, 1989)

2. E. V. Banaev, R. V. Adel'shin, Contemp. Probl. Ecol. 2(6) (2009)

3. M. A. Tomoshevich, Mikol. Fitopatol. 42(5) (2008)

4. S. A. Redhead, Canadian Journal of Botany 63 (1985)

5. U. Braun, V. Melnik, E. Huseyinov, F. Selcuk, Mikol. Fitopatol. 34(6) (2000)

6. S. C. Lee, K. S. Han, J. H. Park, H. D. Shin, Plant Dis. 97(1) (2013)

7. J. H. Park, S.-E. Cho, S. H. Lee, H. D. Shin, J. Phytopathology 161 (2013)

8. U. Braun, V. A. Melnik, M. A. Tomoshevich, Mycol. Balcan. 6 (2009)

9. M. A. Tomoshevich, E. V. Banaev, Contemp. Probl. Ecol. 6(4) (2013)

10. U. Braun, A monograph of Cercosporella, Ramularia and allied genera (Phytopathogenic Hyphomycetes). Vol. 2 (Verlag, Eching, 1998)

11. A. Bartkowska, Phytopatol. Pol. 43 (2007) 